\title{
Asymmetric FDI and Tax-Treaty Bargaining:
}

Theory and Evidence

\author{
Richard Chisik* and Ronald B. Davies ${ }^{* *}$
}

April 2001

Revised June 2001

\begin{abstract}
Tax treaties are often viewed as a mechanism for eliminating tax competition, however this approach ignores the need for bargaining over the treaty's terms. This paper focuses on how bargaining can affect the withholding taxes set under the treaty. In a simple framework, we develop hypotheses about patterns in treaty tax rates. A key determinant for these patterns is the relative size of bilateral foreign direct investment (FDI) activity. In plausible situations, more asymmetric countries will negotiate treaties with higher tax rates. This theory is then tested using 1997 data from U.S. bilateral tax treaties. Overall, the data supports the prediction that greater asymmetric FDI activity increases the negotiated tax rates.
\end{abstract}

\section{JEL Classification: F23, H25, K34.}

Key Words: Foreign Direct Investment, Tax Treaties, Multinational Corporations, Bargaining, Withholding Taxes.

"Department of Economics DM-309C, Florida International University, Miami, FL, 33199; Phone: (305) 348-3286; Fax: (305) 348-1524; E-mail: chisikr@ fiu.edu.

** Department of Economics, 533 PLC Building, 1285 University of Oregon, Eugene, OR 97403-1285; Phone: (541) 346-4671; Fax: (541) 346-1243; E-mail: rdavies@ oregon.uoregon.edu.

We thank participants at the 2001 World Tax Competition, especially John Mutti and William Randolph. All errors are entirely the responsibility of the authors. 
Tax treaties are often viewed as a remedy for tax competition. Under bilateral tax treaties, withholding taxes, tax definitions, and relief methods are chosen jointly by the treaty partners. ${ }^{1}$ In the rubric of game theory, tax treaties move taxation from non-cooperative tax competition to a cooperative setting. Because these policies are now set cooperatively, it is tempting to believe that they eliminate tax competition, however this presumption is misleading since the terms of the treaty (and the distribution of the gains from treaty formation) must be bargained over. If countries differ in their preferred treaties, then there remains unresolved conflict which will be played out through the negotiating process. Thus, rather than eliminating tax competition, tax treaties change the nature of the competition. Recognizing the patterns of this bargaining has important implications for understanding the potential of tax treaties.

This paper makes a first attempt at modeling the conflicting goals in treaty formation by presenting a simple bargaining framework. The implications of the model are then tested using 1992 data from bilateral tax treaties with the United States. On the whole, we find that treaty-specified withholding taxes vary in a systematic way which is consistent with our simple bargaining model. In particular, our results highlight the importance of asymmetries in bilateral FDI activity between the two countries. As the size of this asymmetry grows the scope for cooperation is decreased and the negotiated tax rate is higher. We find similar implications for relative country size. These results indicate that it may be difficult for highly asymmetric countries to negotiate a treaty, and in fact, our analysis suggests that countries with highly asymmetric FDI activity are also the least likely to have a treaty. Since highly asymmetric countries may also engage in the sorts of severe tax competition discussed by Bond and Samuelson (1989), this suggests that in those situations where a cooperative tax treaty may be most beneficial, it may also be the most difficult to agree upon.

The difficulties arising from tax competition are well known (see Wilson (1999) for a recent

${ }^{1}$ For an excellent discussion of the workings of the OECD model tax treaty, see Baker (1994). For additional discussion on some of the primary goals and issues of tax treaties, see Blonigen and Davies (2000). 
survey). As countries unilaterally determine their tax policies, this can create distortions in public good provision, FDI activity, and other decisions. While tax treaties are rarely discussed in this literature, when they are, they are typically presented as a mechanism of eliminating the inefficiencies created by tax competition. In fact, in the OECD's (1997) model treaty, the claim is made that their goal is to reduce the inefficiencies caused by tax competition. Janeba (1995) shows that when taxes are uniform and either foreign tax credits or an exemption is used to combat double taxation, there exists a set of mutually beneficial, harmonized tax rates. Since this is a common provision in tax treaties, Janeba suggests that this provides a role for treaties. Janeba does not, however, discuss how a particular rate is chosen from this set of mutually beneficial taxes. This is the first goal of the present paper.

In addition to the small economic literature on tax treaties, there also exists work by international tax lawyers. These writings often portray treaties in a less-hopeful light than the economic studies do. Dagan (2000), for example, pans the FDI efficiency gains as a myth. Instead, Dagan argues that in U.S. treaty formation two other aspects dominate policy development: reductions in tax losses overseas and alleviation of administration costs. Radaelli (1997) also suggests that U.S. treaty policy is not driven by a desire to improve efficiency, but rather to reduce tax evasion through mechanisms such as transfer pricing. Other gains from treaty formation include information sharing between governments, dispute resolution mechanisms, and coordinated policies on items such as transfer pricing and expense allocation. With these arguments in mind, we assume that a country can benefit from the treaty in two ways. First, by negotiating a lower withholding tax, a country can lower what its investors pay in overseas taxes. Note that this gain for one country is a loss to the other country. Thus, it can easily be the case that under the treaty one country's net tax payment falls while the other's rises. This is the source of contention Dagan focused on. Second, each country experiences an additional gain unrelated to the withholding tax level which arises from reductions in administrative and enforcement costs. In this way, the treaty represents an increase in total surplus for the two countries and they must agree how to 
split these gains between them.

One way to transfer surplus between the countries is through the appropriate choice of a common tax rate. Using a non-symmetric bargaining solution (see, for example, Myerson, p.390, 1991), we solve for the jointly chosen tax rate as a function of relative bargaining strength, relative FDI activity, and nontreaty tax policies. Our second goal is to then test the implications of this solution using 1997 U.S. data. We perform this estimation using both affiliate sales data from the Bureau of Economic Analysis and instruments developed from recent work by Carr, Markusen, and Maskus (forthcoming). We find strongly significant results for the effect of asymmetry in FDI activity on the negotiated tax rates. Our results suggest that as sales from overseas affiliates become unbalanced, the negotiated tax will rise. The signs of the coefficients are consistent with a situation in which changes in tax revenues are highly important to countries. Our proxies for bargaining size do not perform as expected, but do reinforce the idea that more asymmetric countries negotiate higher tax rates. These results are robust under both Tobit estimation and the use of our instruments. Finally, since treaty-negotiated rates are only observed for countries with treaties, we test whether sample selection is driving our results. Using Heckman's (1979) two-step method, we find that our results hold even after controlling for sample selection.

The remainder of the paper is as follows. Section II presents the bargaining model and develops some hypotheses for our estimation. Section III discusses our data and estimation procedure. Results are found in Section IV. Section V concludes.

\section{Bargaining in Tax Treaties}

In order to develop testable hypotheses, in this section we develop a model of bargaining over the treaty-specified withholding tax rates. While this model is admittedly stylized, we use it to explore the conflicts likely to arise in treaty formation and to anticipate what results might be found in the data.

Since the treaties in question are bilateral, consider a setting with two countries, home and 
foreign. Mirroring the data, each country's investors produce at home and abroad. Home's domestic production is $h(K-Z)$ and its overseas production function is $h^{s}(Z)$ where $\mathrm{K}$ is home's capital stock and $\mathrm{Z}$ are its capital outflows. Similarly, foreign's domestic production is $f\left(K^{*}-Z^{*}\right)$ and its overseas production is $f^{s}\left(Z^{*}\right)$. The price of output is constant and equal to one for all four types of production. In this one period model, all overseas profits are repatriated. Upon repatriation, home investors must pay a withholding tax to the foreign country just as foreign investors must pay the home withholding tax.

Without a treaty, the home withholding tax is $\bar{\tau}$ and the foreign withholding tax is $\bar{\tau}^{*}$. Since these nontreaty rates remain the same for non-treaty countries, we treat them as exogenous parameters. ${ }^{2}$ Following the treaty convention, under a treaty each country chooses the same withholding tax $\tau .{ }^{3}$ It is also useful to note that among U.S. treaties, $\tau$ is no greater than either country's non-treaty rate.

Although we do not explicitly model it, we take the "new" view on the effect of withholding taxes which was initiated by Hartman (1985). This theory posits that withholding taxes will have no effect on the size of overseas operations by a mature subsidiary. ${ }^{4}$ This occurs because, given the initial parental capital injection, retained earnings present a less expensive source of investment than repatriated and re-exported funds. Sinn (1993) formalized this result and also found that while withholding taxes do not affect the size of a mature subsidiary, they can impact the initial parental injection of equity.

${ }^{2}$ Our model could easily be extended to include both home and foreign corporate income taxes. Since these do not change under tax treaties, they would cancel out in the bargaining solution. Thus, their inclusion would not alter the model's predictions.

${ }^{3}$ If instead of a common tax rate each country chooses its own treaty-specified tax, then under the Hartman-Sinn analysis there exist a continuum of home and foreign taxes which achieve the same distribution of rents as any given common tax.

${ }^{4}$ It is important to note that the Hartman/Sinn result indicates that withholding taxes should be irrelevant for the size of overseas operations, not that other taxes such as corporate income taxes should be irrelevant. A wealth of evidence, such as that provided by Grubert and Mutti (1999), suggests that these other taxes do affect FDI activity while withholding taxes do not. 
However, as shown by Weichenrieder (1996), even this effect on the initial equity injection need not influence FDI activity if there exist passive investment options in the host country. Grubert (1998) extended the Hartman-Sinn result to a setting in which profits can be repatriated through dividends, royalties, and interest payments and found results similar to Sinn's. Furthermore, as demonstrated by Altshuler and Grubert (1996), there exist costly "triangular" strategies which enable firms to achieve the equivalent repatriation without actually repatriating funds from the host country. Both Grubert (1998) and Grubert and Mutti (1999) provide empirical results consistent with the Hartman/Sinn result. In light of this work, we operate under the assumption that the size of overseas operations (and the $\mathrm{Z}$ and $\mathrm{Z}^{*}$ ) are exogenous to the withholding tax and are therefore determined outside the model. ${ }^{5}$ Note that under this assumption, in equilibrium, one would expect the non-treaty rates to equal one since countries can increase their share of the inbound FDI tax base without affecting the size of that base. This result can be eliminated by extending the model to a setting in which, due to non-tax base costs of taxation such as costly enforcement, equilibrium withholding tax rates would be less than one even under the HartmanSinn result. Since our goal is to describe the treaty-negotiated taxes rather than the non-treaty rates, we set this issue aside and use the current, more direct model. Without loss of generality we label our countries such that home has relatively more overseas output:

$$
h^{s}>f^{s}
$$

In this sense, the home country is large relative to foreign. Note that this does not correspond with the standard trade definition of "large".

In line with Bond and Samuelson (1989), Janeba (1995), and others, we assume that governments maximize national income. In our bilateral context, a country's national income is the sum of the home-

${ }^{5}$ Since the Hartman/Sinn result arises in part because of the firm's ability to defer domestic taxes until repatriation, it may be unwarranted to impose it in a one period model. However, if the present setting is thought of as a single period of a longer, intertemporal interaction, then it is not unreasonable to assume their result within that period. As our goal is to develop some testable predictions for a crosssection of data rather than to restate the Hartman/Sinn analysis, we proceed with the current formulation. 
controlled production and net tax revenue. Thus, home's national income without a tax treaty is:

$$
\bar{Y}=h+h^{s}-\overline{\tau^{*}} h^{s}+\bar{\tau} f^{s} .
$$

Under the tax treaty, two changes occur to home national income. First, with movement to a common withholding tax $\tau$, net tax revenue can change. Second, there is an additional non-revenue gain simply from being part of a treaty. This non-revenue gain can represent reductions in enforcement costs due to increased inter-governmental cooperation, reductions in the wasteful triangulation activities described by Altshuler and Grubert (1996), or Dagan's (2000) administrative savings. In order to keep this effect as general as possible, we simply represent these gains by $\Phi\left(h^{s}, f^{s}\right)$ for home and $\Phi^{*}\left(h^{s}, f^{s}\right)$ for foreign. Both of these functions are non-decreasing in both of their arguments, such that greater FDI activity (either outbound or inbound) can lead to greater non-revenue gains from the treaty. To ease the development of the intuition for our main result, for the moment we assume that the inbound effect is zero, i.e. that $\Phi_{h^{s}}^{*}=\Phi_{f^{s}}=0$. This would be the case if each country is only concerned with saving administrative and enforcement costs and reducing the transfer pricing losses associated with its own outbound FDI. Not surprisingly, when this assumption is relaxed additional interactions are introduced which lead to less clear-cut results. However, as is shown below, under plausible conditions similar results can be found even in this more general case.

Incorporating these changes under the treaty, home income can be written as:

$$
Y=h+h^{S}-\tau\left(h^{s}-f^{s}\right)+\Phi\left(h^{s}, f^{s}\right)
$$

which is again the sum of worldwide sales and net tax revenue with the addition of the non-tax revenue gains from being part of the treaty. Since home is the large country, note that under the treaty it collects negative net tax revenues. Combining equations (2) and (3), home's gain from the treaty is:

$$
Y-\bar{Y}=\bar{\tau}^{*} h^{S}-\bar{\tau} f^{S}-\tau\left(h^{S}-f^{S}\right)+\Phi\left(h^{S}, f^{S}\right)
$$

which is the change in net tax revenue plus the non-tax gains from the treaty. This mirrors Dagan's (2000) belief that reductions in net tax losses and administrative costs are the primary concerns for the 
(relatively large) U.S..

Similar to home, foreign's gain from the treaty is:

$$
Y^{*}-\bar{Y}^{*}=\bar{\tau} f^{S}-\bar{\tau}^{*} h^{S}+\tau\left(h^{S}-f^{S}\right)+\Phi^{*}\left(f^{S}, h^{S}\right)
$$

From the third term in equations (4) and (5), we can see the conflict between countries over the treatyspecified tax rate $\tau$, since increasing $\tau$ shifts gains from the large home country to the small foreign country. Because of this, home prefers a lower $\tau$ while foreign prefers higher tax rates. Since the treaty constitutes a Pareto improvement it must be individually rational for both countries, therefore, $\tau$ is constrained to the set $\left[\frac{\overline{\tau^{*}} h^{s}-\bar{\tau} f^{s}-\Phi^{*}}{h^{s}-f^{s}}, \frac{\overline{\tau^{*}} h^{s}-\bar{\tau} f^{s}+\Phi}{h^{s}-f^{s}}\right]$, with the two countries preferring the opposite ends of this interval. ${ }^{6}$ Anecdotally, the necessity of a mutually-beneficial treaty is illustrated by the U.S. treaty with Honduras which eliminated all withholding taxes. Honduras felt that, since nearly all FDI flowed from the U.S. to Honduras, the treaty only benefitted the U.S., which is akin to a $\tau$ outside of this range. This led Honduras to cancel the treaty in 1966, ten years after its implementation (Diamond and Diamond, 1998).

We appeal to the generalized Nash bargaining solution to derive the result from the bargaining process. This technique indicates that the solution can be found by choosing a $\tau$ which maximizes a weighted product of the two countries' gains from treaty formation. Thus, $\tau$ must satisfy:

$$
\tau(\alpha) \in \arg \max \left[(Y-\bar{Y})^{\alpha}\left(Y^{*}-\bar{Y}^{*}\right)^{1-\alpha}\right]
$$

where $\alpha$ represents the relative bargaining power of the home country. ${ }^{7}$

The maximizing $\tau$ is unique. After some simplification the negotiated tax can be written as:

${ }^{6}$ This finding is comparable to that of Janeba (1995). In his case, capital flows are unilateral, corresponding to $f^{s}=0$. Note that in his model, he discards the Hartman/Sinn assumption and assumes endogenous capital flows. By harmonizing tax rates under a treaty, Janeba shows that surplus is created by improving capital market efficiency, which could also be represented by our $\Phi$ and $\Phi^{*}$. As he notes, there are a range of tax rates which achieve this result. Furthermore, he finds that the relatively large country desires the lowest such tax rate while the smaller country desires the highest one.

${ }^{7}$ Hence, unless $\alpha=1 / 2$ we are abandoning Nash's (1953) symmetry axiom. 


$$
\tau=\frac{\overline{\tau^{*}} h^{s}-\bar{\tau} f^{s}+(1-\alpha) \Phi-\alpha \Phi^{*}}{h^{s}-f^{s}}
$$

Note that when $\alpha=1$ home has all of the bargaining power and the chosen tax is equal to home's most preferred tax rate. Similarly, as $\alpha$ approaches zero, the tax approaches foreign's optimal tax rate.

Substituting the treaty tax rate into equations (4) and (5) we see that the solution distributes income between the countries in the following way:

$$
Y-\bar{Y}=\alpha\left(\Phi+\Phi^{*}\right) \text { and } Y^{*}-\bar{Y}^{*}=(1-\alpha)\left(\Phi+\Phi^{*}\right) .
$$

Hence, the non-revenue gains are split according to each country's bargaining power. By choosing the appropriate tax rate, income is shifted from one country to another such that both are willing to agree to the treaty. In this fashion, a side payment is built into the treaty itself and is reflected in the agreed upon tax rate.

From equation (7), we can derive the following set of comparative statics as well as our main results.

Proposition 1: If $\Phi_{h^{s}}^{*}=\Phi_{f^{s}}=0$, then the comparative static effects of $\bar{\tau}, \bar{\tau}^{*}, \alpha, h^{s}$, and $f^{s}$ on $\tau$ are as follows. Furthermore, the negotiated tax rate is increasing in the asymmetry of outbound FDI levels.

$$
\begin{aligned}
& \frac{\partial \tau}{\partial \bar{\tau}}=\frac{-f^{s}}{h^{s}-f^{s}}<0 \\
& \frac{\partial \tau}{\partial \overline{\tau^{*}}}=\frac{h^{s}}{h^{s}-f^{s}}>0 \\
& \frac{\partial \tau}{\partial \alpha}=\frac{-\Phi-\Phi^{*}}{h^{s}-f^{s}}<0 \\
& \frac{\partial \tau}{\partial \mathrm{h}^{\mathrm{s}}}=\frac{\frac{\tau^{*}}{{ }^{*}}-\tau+(1-\alpha) \Phi_{\mathrm{h}^{\mathrm{s}}}}{\mathrm{h}^{\mathrm{s}}-\mathrm{f}^{\mathrm{s}}}>0 \\
& \frac{\partial \tau}{\partial \mathrm{f}^{\mathrm{s}}}=-\frac{\bar{\tau}-\tau+\alpha \Phi_{\mathrm{f}^{\mathrm{s}}}}{\mathrm{h}^{\mathrm{s}}-\mathrm{f}^{\mathrm{s}}}<0
\end{aligned}
$$


Proof: First remember that without loss of generality we label the countries so that $h^{\mathrm{s}}>\mathrm{f}^{\mathrm{s}}$. The comparative statics then follow from manipulation of the partial derivatives of equation (7).

Furthermore, if $\mathrm{h}^{\mathrm{s}}>\mathrm{f}^{\mathrm{s}}$, then an increase in the asymmetry of FDI levels corresponds to an increase in $\mathrm{h}^{\mathrm{s}}$ and/or a decrease in $\mathrm{f}^{\mathrm{s}}$ and, therefore, from equations (9d) and (9e), $\tau$ is increasing along with this asymmetry.

The intuition behind Proposition 1 is as follows. An increase in the home non-treaty rate means that the foreign country saves more in tax payments for a given treaty tax rate. This foreign windfall is a cost for the home country. To return to the bargaining solution it is, therefore, necessary to transfer surplus from foreign to home, which is achieved by lowering $\tau$. The intuition for a change in $\bar{\tau}^{*}$ is similar. As noted above, when home has more bargaining power, it is able to push more strenuously for its desired low tax rate, yielding a negative derivative.

The comparative static effect of FDI activity on $\tau$ can be described as follows. The first two terms in equation (9d) show the difference between foreign's non-treaty and treaty tax rate. As home's overseas investment rises, this increases home's gain from a tax reduction. At the same time, this lowers foreign's gain from the treaty. This necessitates transferring income from home to foreign to return to the bargaining solution, a result which is achieved by raising $\tau$. This effect is reinforced by the second term, which represents changes in the non-tax gains from treaty formation. An increase in non-tax gains for the home country generates a larger total surplus from the treaty, $(1-\alpha)$ percent of which must be transferred to foreign. Equation (9e) indicates that an increase in $\mathrm{f}^{\mathrm{s}}$ has the opposite effect. Since $h^{s}>f^{s}$, an increase in the asymmetry of FDI levels is generated by an increase in $\mathrm{h}^{\mathrm{s}}$ and/or a decrease in $\mathrm{f}^{\mathrm{s}}$. This increased asymmetry in FDI levels affects the threat point in the bargaining problem and as these threat points become more asymmetric the negotiated tax rate must increase.

Under the more general formulation for $\Phi$ and $\Phi^{*}$, equations (9d) and (9e) become: 


$$
\begin{aligned}
& \frac{\partial \tau}{\partial \mathrm{h}^{\mathrm{s}}}=\frac{\bar{\tau}^{*}-\tau+(1-\alpha) \Phi_{\mathrm{h}^{\mathrm{s}}}-\alpha \Phi_{\mathrm{h}^{\mathrm{s}}}^{*}}{\mathrm{~h}^{\mathrm{s}}-\mathrm{f}^{\mathrm{s}}} \text { and } \\
& \frac{\partial \tau}{\partial \mathrm{f}^{\mathrm{s}}}=-\frac{\bar{\tau}-\tau+\alpha \Phi_{\mathrm{f}^{\mathrm{s}}}^{*}-(1-\alpha) \Phi_{\mathrm{f}^{\mathrm{s}}}}{\mathrm{h}^{\mathrm{s}}-\mathrm{f}^{\mathrm{s}}} .
\end{aligned}
$$

Here, both the third and fourth terms represent changes in the non-tax gains from treaty formation. When $\mathrm{h}^{\mathrm{s}}$ rises, this increases total surplus from the treaty by $\Phi_{h^{s}}+\Phi_{h^{s}}^{*}, \alpha$ percent of which will go to home. Since $\Phi_{h^{s}}$ arises in home directly, to return to the Nash bargaining solution home must transfer the difference between this amount and home's share of the total rise in surplus to foreign. Note that if $\Phi^{*}$ is sufficiently sensitive to $h^{\mathrm{s}}$ or if home's bargaining power is sufficiently large, then a rise in $\mathrm{h}^{\mathrm{s}}$ may require a transfer to home, i.e. a reduction in $\tau$. In this case, the comparative statics in (10) are ambiguous. This leaves us with two situations in which we can unambiguously sign these comparative statics: when revenue changes are larger than the non-revenue changes or when a rise in a country's outbound investment increases the non-revenue gains generated within its borders by more than it increases that country's share of total non-revenue gains. These conditions are summarized by Proposition 2.

Proposition 2: Sufficient conditions for an increase in the asymmetry of FDI levels to generate an increase in the treaty tax rate are that:

a) revenue effects are larger than non-revenue effects,

or

$$
\text { b) that } \frac{\Phi_{h^{s}}}{\Phi_{h^{s}}^{*}}>\frac{\alpha}{1-\alpha} \text { and that } \frac{\Phi_{f^{s}}^{*}}{\Phi_{f^{s}}}>\frac{1-\alpha}{\alpha} \text {. }
$$

With these predictions in hand, we now turn to data on U.S. bilateral treaties to test their plausibility. 


\section{Empirical Methodology and Data}

To test the predictions of our theory, we use 1997 data between the U.S. and its bilateral tax treaty partners. Since treaties affect four different withholding taxes, for each country pair we consider four different tax rates: that on dividends paid to the parent, that on non-affiliated dividends, that on nonfinancial interest payments, and that on industrial royalty payments. Although we believe the above model describes the tradeoffs in treaty formation, we hesitate to suggest that it closely approximates the actual functional forms of reality. Therefore, rather than estimate a variant of the structural equation (7), we estimate the following reduced-form equation:

$$
\tau_{i j}=\tau\left(h_{i}^{s}, f_{i}^{s}, \overline{\tau_{i j}}, \overline{\tau_{i j}^{*}}, \alpha_{i}, D_{j}\right)
$$

where $\mathrm{i}$ is the U.S. treaty partner and $\mathrm{j}$ is the type of withholding tax. The first five right hand side variables are defined as in the theory, that is, $\mathrm{h}^{\mathrm{s}}$ is the value of overseas FDI production by the relatively large country, $\mathrm{f}^{\mathrm{s}}$ is the value of overseas FDI production by the relatively small country, etc.. The final term, $\mathrm{D}$, is a constant plus a set of dummy variables for the parental dividend tax, the unrelated dividend tax, and the royalty tax.

The information on the treaty-specified tax rates is drawn from the treaties themselves as reprinted in Diamond and Diamond (1998). For measures of $h^{s}$ and $f^{s}$, we use 1997 affiliate sales of nonfinancial institutions in the host country, which can be obtained from the Bureau of Economic Analysis' website. $^{8}$ This year was chosen because it is the most recent for which we could obtain bilateral affiliate sales. It should be noted that if these sales report the actions of a single firm, then the BEA censors this data, deleting some treaty partners from our sample. In order to classify countries as home or foreign, we compared the relative sales of the two countries for each year that sales data was available and designated the one which had higher affiliate sales in the most number of years "home". As a result, France was designated "foreign" even though it had greater sales in the U.S. during 1997 than the U.S.

\footnotetext{
${ }^{8}$ As of the time of this paper, this website is http://www.bea.doc.gov/bea/di1.htm.
} 
had there. This was the only year since 1984 in which French-owned affiliates had greater sales. ${ }^{9}$ With a few exceptions, this coding means that the U.S. plays the part of the home country. Data on non-treaty rates are obtained from the Price-Waterhouse Corporate Taxes - A Worldwide Summary (1992). Because the U.S. is almost always the home country and all U.S. non-treaty withholding tax rates were $30 \%$, the home non-treaty tax is nearly constant.

It is less obvious what measure to use for the home country's bargaining power. Because of this, we use three proxies for home bargaining power, all of which are based on the idea that a country with a larger economy will have more sway in the negotiations. One rationale for this presumption is that a small country might choose to appease a large one in the hopes of future concessions on other international agreements such as trade pacts. The first proxy is the home country's share of the total gross domestic products (GDP) of the two countries. The second measure is the ratio of home GDP to foreign GDP. Finally, we simply include the home and foreign countries' GDPs independently. Data on real GDP come from the World Bank's World Development Indicators (1999). Again, since the U.S. is almost always the home country, home country GDP has little variation. Note that by using this crosssectional approach, we are testing for systematic variation in the long-run equilibrium of the bargaining game between countries rather than the marginal effect of changes in our explanatory variables. Summary statistics for our data are found in Table A1 of the appendix. Table A2 lists the thirty-one treaty partners used in our estimation.

In the theory, we make great use of the Hartman/Sinn result that overseas affiliate sales are unresponsive to the withholding taxes. This assumption need not hold in the data and, therefore, in addition to the FDI variables reported by the BEA, we also run estimations that instrument for affiliate sales. While gravity models have been popular specifications for affiliate sales, they were developed more in response to the data than to the theory of the multinational enterprise (MNE). Instead we

\footnotetext{
${ }^{9}$ If France is instead coded as "home", we find qualitatively similar results.
} 
develop our instruments from recent work by Carr, Markusen, and Maskus (forthcoming) and Markusen and Maskus (1999a, 1999b) who establish empirical specifications of FDI activity that are arguably more grounded in the formal theories of multinational firms. In particular, Markusen and Maskus provide an empirical model of FDI activity that nests three alternative theories: the horizontal model, the vertical model, and the knowledge-capital model which integrates the other two. Markusen and Maskus (1999b) use their empirical model to examine affiliate sales of U.S. firms in other countries and foreign affiliate sales in the U.S. over the period 1986-1994. Their unrestricted specification fits their data quite well and, in general, finds support for the horizontal MNE theoretical model. Details of the MarkusenMaskus approach, as well as the results used to instrument affiliate sales, are found in the appendix. Because of the limited availability of some of the information required for this approach, we were forced to use 1992 data to create our instruments. As a result, it is necessary to compare our findings from the actual 1992 data to those using the 1997 data as well as those using the instruments. Here, we merely note that the M-M model does reasonably well in capturing the variation in affiliate sales with $\mathrm{R}^{2} \mathrm{~s}$ for home and foreign affiliate sales of .9740 and .9196 respectively.

Before turning to our estimation results, three issues deserve mention. First, since these data are available for more than one year, it is tempting to use a panel data specification. Unfortunately, during the period for which sales data is available, there is insufficient within-treaty variation in the treatyspecified tax rates for this approach to be useful. Second, although the treaty tax rates do vary across types of withholding taxes within a country pair our other variables, naturally, do not vary within our single year sample. This precludes the use of country-specific fixed effects. It can also cause clustering effects, as discussed by Kloek (1981), which can lead to understated standard errors, a problem we deal with below. Finally, treaty tax rates are only observed for countries with treaties. Therefore, it is necessary to ask how this sample selection impacts our results. 


\section{Results}

Tables 1 through 3 present the baseline estimation results using each of the three proxies for home bargaining power. Each table contains three estimation specifications using the BEA's reported affiliate sales. The first column is OLS using White's (1980) corrected standard errors. Since there are four tax rates (and four observations) for each country pair, it may be necessary to control for country clusters. Column two lists the results after performing this correction as described by Rodgers (1993). Finally, since no withholding taxes are below zero, the last column uses the Tobit estimation procedure for a dependent variable restricted to non-negative values. In addition to the reported independent variables, each of these regressions includes a constant as well as dummy variables for the parental dividend, unrelated dividend, and royalty tax. The results for these are omitted for space but are available upon request.

Regardless of whether we use OLS or Tobit, we find similar results on affiliate sales. Home sales are positively and significantly correlated with the treaty tax. Foreign affiliate sales have a significant, negative coefficient in all specifications. This significance remains even after correcting for clustering. Since the treaties in our sample lower tax rates, these results are consistent with two situations: revenue effects dominate or, as described in Proposition 2, the parent's marginal non-revenue gain is larger than the host's. Since these variables' coefficients have opposite signs, this suggests that a rise in asymmetry leads to higher negotiated tax rates. The magnitudes of the coefficients on home and foreign affiliate sales center around .0000328 and -.0000701 respectively. This indicates that an increase in home affiliate sales of $\$ 1$ billion would increase the negotiated tax by $.0328 \%$. An equivalent increase in foreign affiliate sales would lower the negotiated tax by $.0701 \%$. While these magnitudes seem small, consider them in the following light: if the U.S. were to increase its affiliate sales in Indonesia from $\$ 10$ billion to the $\$ 446$ billion it had in Japan, the estimated Indonesian tax on dividends paid to parents would rise from $10 \%$ to over $24 \%$. Thus these results suggest economically meaningful effects from 
asymmetric FDI flows.

In all but one specification, the foreign non-treaty tax is positive and significant as predicted by the theory. Thus, when the foreign country has an initially high tax rate, the negotiated tax is also higher on average. Contrary to theory, the coefficient on the home non-treaty tax is also positive and frequently significant. This result, however, may be due to the limited variation in this tax since the U.S. is almost always the home country.

None of the proxies for bargaining power perform well relative to our prior expectations. The coefficient on the home share of combined GDP is positive and highly significant. Relative home GDP is also positive, although it is not significant. Finally, when we include both home and foreign GDP separately we find that both have positive coefficients though only the coefficient on home GDP is significant. Since home GDP is nearly constant, the meaning of the significance of home GDP alone is questionable. As a whole, these results suggest three possibilities. First, we may simply have poor proxies of bargaining power although this does not explain the strong significance of the home share of combined GDP. Second, the U.S., who is almost always home, may have an idiosyncratic preference for higher taxes that is unaccounted for by the theory. Because of this preference, when the U.S. has greater bargaining power higher tax rates are negotiated. This interpretation, however, runs counter to the fact that the U.S. is a relatively low-tax country when compared to other developed nations. Finally, our expectation that larger countries hold more bargaining power could be incorrect. Park (2000) shows that a small country may be able to inflict a greater punishment on a large trading partner in the event of a trade war. As a result, it holds more bargaining power in trade negotiations. In a similar way, if small countries are able to establish a more effective threat in tax treaty negotiations, then they may be able to negotiate their preferred higher tax rates. Such threats could be economic or political. For example, since relatively small countries do not support large international military operations, they are far more likely to host a U.S. military base than the U.S. is to host one of their bases. The threat of expulsion 
might tip the balance in favor of the small country resulting in higher tax rates. In any case, these results indicated that similar to the asymmetries in FDI activity, asymmetries in GDPs are associated with higher tax rates. The results also point out the need for additional research on the determinants of bargaining power in international agreements.

In an attempt to correct for possible effects of withholding taxes on affiliate sales, we now turn to the instrumented values for home and foreign sales. As noted above, because of data limitations, it is necessary to use 1992 data to create our instruments. Table 4 presents the estimates using the actual 1992 data and the results using the instruments. ${ }^{10}$ The results for both of these estimation specifications are broadly consistent with the results from the 1997 data. With the exception of the specification in which GDPs are included separately, positive and significant coefficients are found on home sales. In that case, similar coefficients are estimated but their significance falls below the $10 \%$ level. This is possibly due to collinearity between these two variables arising from the instrument's construction. Negative and significant coefficients are found for foreign sales in all specifications. These findings reinforce the importance of asymmetry in FDI activity for the bargaining process. The results for the non-treaty tax rates are less significant, possibly due to the drop in the number of observations. The bargaining proxies are also less significant, although they paint a similar picture as those above. One interesting difference is that the coefficient on relative home GDP is now negative and weakly significant. This may be driven by the fact that using the 1992 sample excludes recent treaties with developing countries, suggesting that the determinants of relative bargaining power may differ depending on whether one or both treaty partners are developed. Given our small sample size, these results must be taken with a grain of salt, however, the similarity between the instrumented results and those from the actual data suggests that potential endogenity of affiliate sales is not a crippling issue for our results.

${ }^{10}$ Tobit results using the 1992 data and the instruments are also consistent with the 1997 results and are available upon request. 
As a final robustness test, we investigate the impact of sample selection since treaty-specified tax rates are only observed for countries which actually have treaties. To examine the impact this may have, we turn to Heckman's (1979) two-step process. This process first estimates the likelihood of the dependent variable (a treaty-specified tax rate) being observed using Probit estimation. Then, a second step estimates the impact of our independent variables conditional on the results from the first step. To carry out this estimation, we expand our 1997 data set to cover all countries for which the necessary variables were available from the above-cited sources. This results in forty-nine countries, thirty-one of which had treaties. The results from the selection step are in Table 5. As that table shows, the data suggest that asymmetries are important for the simple existence of a treaty, regardless of its actual terms. Specifically, as the small foreign country's affiliate sales rise, this significantly increases the probability of a treaty. The significant negative coefficient on home sales tells the same story. Therefore, the data suggest that as the difference between the countries FDI levels shrinks, the probability of a treaty grows. The non-treaty taxes are generally positive and significant, lending credence to the idea that countries may seek out treaties in order to reduce the taxes paid to the overseas government. Finally, the relative GDP measures give conflicting results since a larger home share of GDP seems to raise the likelihood of a treaty while a larger relative GDP lowers the likelihood.

The second step of Heckman's procedure estimates coefficients for the independent variables conditional on an observed country having a treaty. These results are reported in Table 6 and are very similar to the above findings. Again, we find statistically significant estimates on both home and foreign affiliate sales which indicate that as the asymmetry in FDI activity rises, so does the negotiated tax rate. Whereas the home non-treaty tax is no longer significant, the foreign non-treaty tax is still positive and significant in two of the three specifications. The bargaining proxy coefficients also mirror the sign and significance of those in Tables 1 through 3.

Combining all of these results indicates that asymmetries, particularly in bilateral FDI activity, 
have a significant and economically meaningful impact on treaty formation. Not only are dissimilar countries less likely to form a treaty, but even those that do reach the negotiating table may find themselves with directly opposing goals.

\section{Conclusion}

In this paper, we have made a first attempt at modeling the bargaining process behind bilateral tax treaty development. Following the work in international tax law, the theory highlights two main areas of conflict: changes in tax revenue and sharing the non-revenue gains from treaty creation. The predictions from this theory were then tested with data from U.S. treaties. The data indicates significant and robust patterns in tax rates across treaty partners, particularly for affiliate sales. While our approach has been admittedly simple, we believe it makes three key points. First, tax treaties do not eliminate tax competition, but only change its nature. Second, the terms of tax treaties vary in a systematic way across countries. Third, asymmetries in FDI levels affect the threat point in the bargaining problem. As these asymmetries rise, the scope of possible cooperative outcomes is diminished which in turn can either increase the negotiated tax rates or put a stop to treaty formation altogether. Although the Hartman/Sinn analysis argues that withholding taxes should not affect the amount of FDI activity, if FDI is partly influenced by taxes, then the inefficiencies from tax competition may also remain. Similar problems may arise as governments butt heads over other treaty provisions such as jurisdiction, tax definitions, and the like. Our results indicate that these issues may be a particular concern for highly asymmetric countries. This concern is heightened given the results from Bond and Samuelson (1989) and others who find that highly asymmetric countries may engage in the most severe tax competition. Combining their work with ours, this suggests that the countries most in need of tax coordination may also be the least likely to achieve it. Recognizing how these treaty policies are determined in this "cooperative" setting is therefore important in reducing the inefficiencies from double taxation. Additionally, if treaty-specified tax policy 
has efficiency implications beyond FDI, then understanding treaty formation is necessary in order to effectively use them to mitigate the effects of tax competition. We hope that the results presented here serve as a first step in this direction. 
Table 1: Treaty-specified Withholding Taxes using Home Share of GDP as a Measure of Bargaining Power

\begin{tabular}{|c|c|c|c|}
\hline & OLS & OLS with cluster correction & Tobit \\
\hline Home sales & $\begin{array}{c}.0000291^{* * *} \\
(3.102)\end{array}$ & $\begin{array}{l}.0000291^{* *} \\
(2.084)\end{array}$ & $\begin{array}{c}.0000421^{* * * *} \\
(3.136)\end{array}$ \\
\hline Foreign sales & $\begin{array}{c}-.0000609^{* * * *} \\
(4.621)\end{array}$ & $\begin{array}{c}-.0000609^{* * *} \\
(3.408)\end{array}$ & $\begin{array}{c}-.0000836^{* * *} \\
(4.188)\end{array}$ \\
\hline Foreign non-treaty tax & $\begin{array}{c}.1551257^{* * *} \\
(2.630)\end{array}$ & $\begin{array}{c}.1551257^{* *} \\
(2.049)\end{array}$ & $\begin{array}{c}.1919155^{* * *} \\
(2.939)\end{array}$ \\
\hline $\begin{array}{l}\text { Home non-treaty } \\
\text { tax }\end{array}$ & $\begin{array}{c}.0956997^{*} \\
(1.881)\end{array}$ & $\begin{array}{c}.0956997^{*} \\
(1.777)\end{array}$ & $\begin{array}{l}.2339074 \\
(1.379)\end{array}$ \\
\hline Home share of GDP & $\begin{array}{c}4.686213^{* * * *} \\
(3.819) \\
\end{array}$ & $\begin{array}{c}4.686213^{* * * *} \\
(3.130) \\
\end{array}$ & $\begin{array}{c}5.431016^{* * * *} \\
(2.811) \\
\end{array}$ \\
\hline $\mathrm{N}$ & 124 & 124 & 124 \\
\hline Adjusted $\mathrm{R}^{2}$ & .4670 & .4670 & \\
\hline Pseudo- $\mathrm{R}^{2}$ & & & .1125 \\
\hline
\end{tabular}

All equations also have a constant and dummy variables for the parental dividend, unrelated dividend, and interest tax.

White-corrected t- values in parenthesis.

**** Significant at the $1 \%$ level.

** Significant at the $5 \%$ level.

* Significant at the $10 \%$ level. 
Table 2: Treaty-specified Withholding Taxes using Relative Home GDP as a Measure of Bargaining Power

\begin{tabular}{|l|c|c|c|}
\hline & OLS & OLS with cluster correction & Tobit \\
\hline Home sales & $\begin{array}{c}.0000286^{* * *} \\
(3.352)\end{array}$ & $\begin{array}{c}.0000286^{* *} \\
(2.389)\end{array}$ & $\begin{array}{c}.0000419^{* * * *} \\
(3.014)\end{array}$ \\
\hline Foreign sales & $\begin{array}{c}. .0000593^{* * *} \\
(4.881)\end{array}$ & $\begin{array}{c}.0000593^{* * *} \\
(3.970)\end{array}$ & $\begin{array}{c}. .0000828^{* * *} \\
(4.012)\end{array}$ \\
\hline Foreign non-treaty tax & $\begin{array}{c}.1257947^{* *} \\
(2.089)\end{array}$ & $\begin{array}{c}.1257947 \\
(1.531)\end{array}$ & $\begin{array}{c}.1590045^{* *} \\
(2.376)\end{array}$ \\
\hline Home non-treaty & $\begin{array}{c}.2020035^{* * *} \\
(3.848)\end{array}$ & $\begin{array}{c}.2020035^{* * *} \\
(3.392)\end{array}$ & $\begin{array}{c}.3594992^{* * *} \\
(2.122)\end{array}$ \\
\hline tax & .0141054 & .0141054 & .0158941 \\
$(0.881)$ & $(0.536)$ & $(0.954)$ \\
\hline Relative Home GDP & & & 124 \\
\hline N & 124 & 124 & .1032 \\
\hline Adjusted R & .4334 & .4334 & \\
\hline Pseudo-R & & & \\
\hline
\end{tabular}

All equations also have a constant and dummy variables for the parental dividend, unrelated dividend, and interest tax.

White-corrected t- values in parenthesis.

*** Significant at the $1 \%$ level.

*** Significant at the $5 \%$ level.

* Significant at the $10 \%$ level. 
Table 3: Treaty-specified Withholding Taxes using Home GDP and Foreign GDP as Measures of Bargaining Power

\begin{tabular}{|c|c|c|c|}
\hline & OLS & OLS with cluster correction & Tobit \\
\hline Home sales & $\begin{array}{l}.0000216^{* *} \\
(2.018)\end{array}$ & $\begin{array}{c}.0000216 \\
(1.501)\end{array}$ & $\begin{array}{c}.0000322^{* * *} \\
(2.253)\end{array}$ \\
\hline Foreign sales & $\begin{array}{c}-.0000564^{* * *} \\
(4.025)\end{array}$ & $\begin{array}{c}-.0000564^{* * *} \\
(3.055)\end{array}$ & $\begin{array}{c}-.0000778^{* * * *} \\
(3.871)\end{array}$ \\
\hline Foreign non-treaty tax & $\begin{array}{l}.1532732^{* *} \\
(2.583)\end{array}$ & $\begin{array}{c}.1532732^{* * *} \\
(1.985)\end{array}$ & $\begin{array}{c}.1926171^{* * *} \\
(2.999)\end{array}$ \\
\hline $\begin{array}{l}\text { Home non-treaty } \\
\operatorname{tax}\end{array}$ & $\begin{array}{c}.0967958^{* * *} \\
(2.107)\end{array}$ & $\begin{array}{c}.0967958^{* * *} \\
(2.056)\end{array}$ & $\begin{array}{c}.2682429 \\
(1.440)\end{array}$ \\
\hline Home GDP & $\begin{array}{c}1.26 \mathrm{e}-06^{* *} \\
(2.526)\end{array}$ & $\begin{array}{c}1.26 \mathrm{e}-06^{*} \\
(1.943)\end{array}$ & $\begin{array}{c}1.68 \mathrm{e}-06^{* * *} \\
(2.696)\end{array}$ \\
\hline Foreign GDP & $\begin{array}{c}6.61 \mathrm{e}-07 \\
(1.300)\end{array}$ & $\begin{array}{c}6.61 \mathrm{e}-07 \\
(0.975)\end{array}$ & $\begin{array}{c}9.72 \mathrm{e}-07 \\
(1.611)\end{array}$ \\
\hline $\mathrm{N}$ & 124 & 124 & 124 \\
\hline Adjusted $\mathrm{R}^{2}$ & .4775 & .4775 & \\
\hline Pseudo- $\mathrm{R}^{2}$ & & & .1188 \\
\hline
\end{tabular}

All equations also have a constant and dummy variables for the parental dividend, unrelated dividend, and interest tax.

White-corrected t- values in parenthesis.

*** Significant at the $1 \%$ level.

** Significant at the $5 \%$ level.

${ }^{*}$ Significant at the $10 \%$ level. 
Table 4: Treaty-specified Withholding Taxes using Instruments for Affiliate Sales (1992 data)

\begin{tabular}{|c|c|c|c|c|c|c|}
\hline & Actual data & Instruments & Actual data & Instruments & Actual data & Instruments \\
\hline Home sales & $\begin{array}{c}.0000452^{* * *} \\
(4.293)\end{array}$ & $\begin{array}{c}.0000323^{* *} \\
(2.393)\end{array}$ & $\begin{array}{c}.0000445^{* * *} \\
(4.368)\end{array}$ & $\begin{array}{c}.0000316^{* *} \\
(2.356)\end{array}$ & $\begin{array}{c}.000036^{* *} \\
(2.429)\end{array}$ & $\begin{array}{c}.0000222 \\
(1.439)\end{array}$ \\
\hline Foreign sales & $\begin{array}{c}-.0000615^{* * * *} \\
(3.808)\end{array}$ & $\begin{array}{c}-.0000461^{*} \\
(1.950)\end{array}$ & $\begin{array}{c}-.0000639^{* * * *} \\
(4.048)\end{array}$ & $\begin{array}{c}-.0000487^{* *} \\
(2.035)\end{array}$ & $\begin{array}{c}-.0000559^{* * * *} \\
(3.119)\end{array}$ & $\begin{array}{c}-.0000431^{*} \\
(1.820)\end{array}$ \\
\hline Foreign non-treaty tax & $\begin{array}{l}.061128 \\
(0.985)\end{array}$ & $\begin{array}{c}.0721507 \\
(1.060)\end{array}$ & $\begin{array}{c}.0148135 \\
(0.270)\end{array}$ & $\begin{array}{c}.0264732 \\
(0.429)\end{array}$ & $\begin{array}{c}.0589296 \\
(0.945)\end{array}$ & $\begin{array}{c}.0669362 \\
(0.999)\end{array}$ \\
\hline $\begin{array}{l}\text { Home non-treaty } \\
\text { tax }\end{array}$ & $\begin{array}{c}.0827781^{* *} \\
(2.062)\end{array}$ & $\begin{array}{c}.0728262^{*} \\
(1.696)\end{array}$ & $\begin{array}{c}.1738404^{* * *} \\
(3.376)\end{array}$ & $\begin{array}{c}.1633251^{* * *} \\
(3.022)\end{array}$ & $\begin{array}{c}.0746947^{*} \\
(1.910)\end{array}$ & $\begin{array}{c}.0684061 \\
(1.661)\end{array}$ \\
\hline Home share of GDP & $\begin{array}{c}2.409467^{* *} \\
(2.132)\end{array}$ & $\begin{array}{c}2.391502^{*} \\
(1.919)\end{array}$ & & & & \\
\hline Relative Home GDP & & & $\begin{array}{c}-.0246125^{*} \\
(1.952)\end{array}$ & $\begin{array}{c}-.0244796 * \\
(1.816)\end{array}$ & & \\
\hline Home GDP & & & & & $\begin{array}{c}1.82 \mathrm{e}-06 \\
(1.460)\end{array}$ & $\begin{array}{c}2.41 \mathrm{e}-06^{*} \\
(1.962)\end{array}$ \\
\hline Foreign GDP & & & & & $\begin{array}{c}1.33 \mathrm{e}-06 \\
(1.015)\end{array}$ & $\begin{array}{c}1.95 \mathrm{e}-06 \\
(1.512)\end{array}$ \\
\hline $\mathrm{N}$ & 80 & 80 & 80 & 80 & 80 & 80 \\
\hline Adjusted $\mathrm{R}^{2}$ & .5241 & .5040 & .5247 & .5047 & .5307 & .5200 \\
\hline
\end{tabular}

All equations also have a constant and dummy variables for the parental dividend, unrelated dividend, and interest tax.

White-corrected t- values are in parenthesis.

*** Significant at the $1 \%$ level.

** Significant at the 5\% level.

${ }^{*}$ Significant at the $10 \%$ level. 
Table 5: Testing for Sample Selection using Heckman's Two-Step Procedure

Step 1: Probit Results for Choice of Treaty Partner

\begin{tabular}{|c|c|c|c|}
\hline Home sales & $\begin{array}{c}-.0000162^{* *} \\
(2.544)\end{array}$ & $\begin{array}{c}-.0000168^{* * * *} \\
(2.830)\end{array}$ & $\begin{array}{c}-.0000507^{* * *} \\
(3.560)\end{array}$ \\
\hline Foreign sales & $\begin{array}{c}.0001645^{* * *} \\
(3.641)\end{array}$ & $\begin{array}{c}.0000931^{* * * *} \\
(3.559)\end{array}$ & $\begin{array}{c}.00002842^{* * * *} \\
(4.005)\end{array}$ \\
\hline Foreign non-treaty tax & $\begin{array}{l}.0257016^{* *} \\
(2.405)\end{array}$ & $\begin{array}{c}.0153268 \\
(1.435)\end{array}$ & $\begin{array}{c}.0295748^{* * *} \\
(2.586)\end{array}$ \\
\hline $\begin{array}{l}\text { Home non-treaty } \\
\operatorname{tax}\end{array}$ & $\begin{array}{l}.057221^{\text {**** }} \\
(2.948)\end{array}$ & $\begin{array}{c}.0850412^{* * * *} \\
(5.223)\end{array}$ & $\begin{array}{c}.0590375^{* * *} \\
(2.741)\end{array}$ \\
\hline Home share of GDP & $\begin{array}{c}1.455491^{* * *} \\
(2.688)\end{array}$ & & \\
\hline Relative Home GDP & & $\begin{array}{c}-.0069849^{* * *} \\
(3.711)\end{array}$ & \\
\hline Home GDP & & & $\begin{array}{l}3.34 \mathrm{e}-06^{* * * *} \\
(3.556)\end{array}$ \\
\hline Foreign GDP & & & $\begin{array}{c}3.05 \mathrm{e}-06^{* * *} \\
(3.321)\end{array}$ \\
\hline $\mathrm{N}$ & 196 & 196 & 196 \\
\hline Pseudo-R ${ }^{2}$ & .2963 & .3529 & .4277 \\
\hline
\end{tabular}

The estimated equations also have a constant and dummy variables for the parental dividend, unrelated dividend, and interest tax.

Heckman's consistent Z-values in parenthesis.

*** Significant at the $1 \%$ level.

*** Significant at the $5 \%$ level.

* Significant at the $10 \%$ level. 
Table 6: Testing for Sample Selection using Heckman's Two-Step Procedure

Step 2: Treaty-specified Withholding Taxes Conditional on Treaty

\begin{tabular}{|c|c|c|c|}
\hline Home sales & $\begin{array}{l}.0000291^{*} \\
(1.914)\end{array}$ & $\begin{array}{c}.0000272^{*} \\
(1.646)\end{array}$ & $\begin{array}{l}.0000203 \\
(1.323)\end{array}$ \\
\hline Foreign sales & $\begin{array}{c}-.0000544^{* * *} \\
(2.301)\end{array}$ & $\begin{array}{c}-.000523^{*} \\
(1.647)\end{array}$ & $\begin{array}{c}-.0000526^{* *} \\
\quad(2.435)\end{array}$ \\
\hline Foreign non-treaty tax & $\begin{array}{c}.1747618^{* * *} \\
(2.014) \\
\end{array}$ & $\begin{array}{c}.1359946 \\
(1.184) \\
\end{array}$ & $\begin{array}{c}.1619285^{* *} \\
(1.981)\end{array}$ \\
\hline $\begin{array}{l}\text { Home non-treaty } \\
\operatorname{tax}\end{array}$ & $\begin{array}{l}.103003 \\
(0.388)\end{array}$ & $\begin{array}{l}.2231853 \\
(0.915)\end{array}$ & $\begin{array}{c}.0964061 \\
(0.379)\end{array}$ \\
\hline Home share of GDP & $\begin{array}{c}5.003701^{\text {*** }} \\
(2.415)\end{array}$ & & \\
\hline Relative Home GDP & & $\begin{array}{l}.0071565 \\
(0.112)\end{array}$ & \\
\hline Home GDP & & & $\begin{array}{c}1.44 \mathrm{e}-06^{* *} \\
(2.352)\end{array}$ \\
\hline Foreign GDP & & & $\begin{array}{c}8.01 \mathrm{e}-07 \\
(1.445) \\
\end{array}$ \\
\hline Mills Ratio & $\begin{array}{l}2.048057 \\
(0.710)\end{array}$ & $\begin{array}{l}2.197663 \\
(0.353)\end{array}$ & $\begin{array}{l}1.15001 \\
(0.368)\end{array}$ \\
\hline $\mathrm{N}$ & 124 & 124 & 124 \\
\hline
\end{tabular}

The estimated equations also have a constant and dummy variables for the parental dividend, unrelated dividend, and interest tax.

Heckman's consistent Z-values in parenthesis.

${ }^{* * *}$ Significant at the $1 \%$ level.

*** Significant at the $5 \%$ level.

* Significant at the $10 \%$ level. 


\section{References}

Altshuler, Rosanne and Harry Grubert (1996), "Balance sheets, multinational financial policy and the cost of capital at home and abroad," NBER Working Paper 5810.

Baker, Philip (1994), Double Taxation Conventions and International Tax Law: A manual on the OECD model tax convention on income and on capital of 1992, Second Edition, Sweet \& Maxwell, London.

Bali Online Corporation (1999) http://www.indo.com.

Blonigen, Bruce A. and Ronald B. Davies (2000), "The effects of bilateral tax treaties on U.S. FDI activity," NBER Working Paper, No. 7929.

Bond, Eric and Larry Samuelson (1989), "Strategic behaviour and the rules for international taxation of capital," Economic Journal, 99:1099-1111.

Bureau of Economic Analysis (1998), Detailed annual balance of payments and position estimates, Bureau of Economic Analysis International Data, Washington, D.C.

Carr, David, James R. Markusen, and Keith E. Maskus (forthcoming), "Testing the knowledge capital model of the multinational enterprise," American Economic Review.

Dagan, Tsilly (2000), “The tax treaties myth," New York University Journal of International Law and Politics, Summer 2000, pp. 939-996.

Diamond, Walter and Dorothy Diamond (1998), International Tax Treaties of All Nations, Ocean Publications, Dobbs Ferry, New York.

Grubert, Harry (1998), "Taxes and the division of foreign operating income among royalties, interest, dividends, and retained earnings," Journal of Public Economics, 68, pp. 269-290.

Grubert, Harry and John Mutti (1999), "Dividend exemption versus the current system for taxing foreign business income," Working Paper.

Hartman, David (1985), "Tax policy and foreign direct investment," Journal of Public Economics, pp. 107-121.

Heckman, James (1979), “Sample selection bias as a specification error,” Econometrica, 47, pp. 153-161.

Janeba, Eckhard (1995), "Corporate income tax competition, double taxation treaties, and foreign direct investment," Journal of Public Economics, 56:311-325.

Kloek, Teun (1981), "OLS estimation in a model where a microvariable is explained by aggregates and contemporaneous disturbances are equicorrelated," Econometrica, 49:1, pp. 205-207.

Markusen, James R. and Keith E. Maskus (1999a), "Multinational firms: reconciling theory and evidence," National Bureau of Economic Research Working Paper Series, No. 7163. 
Markusen, James R. and Keith E. Maskus (1999b), "Discriminating among alternative theories of the multinational enterprise," National Bureau of Economic Research Working Paper Series, No. 7164.

Myerson, Roger B. (1991), Game Theory: Analysis of Conflict, Harvard University Press, Cambridge, Massachusetts.

Nash, John (1953), “Two-person cooperative games,” Econometrica, 18, pp. 155-162.

Nehru, Vikram, and Ashok Dhareshwar (1993), "A new database on physical capital stock: sources, methodology and results." Rivista de Analisis Economico, 8:1, pp. 37-59.

Organization for Economic Cooperation and Development (1997), Model tax convention on income and on capital, OECD Committee on Fiscal Affairs, Paris.

Park, Jee-Hyeong (2000), "International trade agreements between countries of asymmetric size," Journal of International Economics, 50:2, pp. 473-95.

Price-Waterhouse (1992), Corporate Taxes: A Worldwide Summary, I. Richard Wood ed., New York.

Radaelli, Claudio M. (1997), The politics of corporate taxation in the European Union, Routledge Research in European Public Policy, London.

Rogers, W. H. (1993), "Regression standard errors in clustered samples," Stata Technical Bulletin, 13, pp. 19-23.

Sinn, Hans-Werner (1993), "Taxation and the birth of foreign subsidiaries," Trade, Welfare, and Economic Policies, Essays in Honor of Murray C. Kemp, ed. H Heberg and N. Long, University of Michigan Press, Ann Arbor.

Summers, Robert and Alan Heston (1991), "The Penn-World Table (Mark 5): an expanded set of international comparisons, 1950 - 1988,” Quarterly Journal of Economics, 106:327-368.

Weichenrieder, Alfons (1996), "Anti-tax-avoidance provisions and the size of foreign direct investment," International Tax and Public Finance, 3:1, pp. 67-81.

White, Halbert (1980), "A heteroskedasticity-consistent covariance matrix estimator and a direct test for heteroskedasticity," Econometrica, 48:4, pp. 817-830.

Wilson, John D. (1999), “Theories of tax competition,” National Tax Journal, 52:2, pp. 269-304.

World Bank (1999), World Development Indicators CD-ROM, Washington, D.C.. 


\section{Appendix}

To facilitate an understanding of our instrumental variables we now, briefly, describe the Markusen and Maskus (M-M) empirical model which is specified by the following equation:

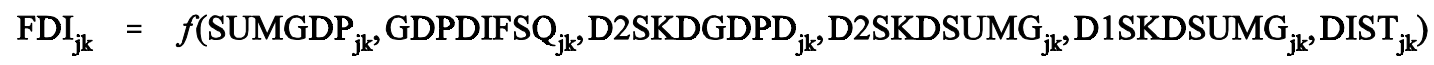

Subscript $\mathrm{j}$ refers to the parent country and k refers to the host country. The first five independent variables on the right hand side of equation (12) are the variables specific to the M-M framework. The first two terms are relatively straightforward, with SUMGDP defined as the sum of the two countries' real GDPs, and GDPDIFSQ defined as the squared difference between the two countries' real GDP. If horizontal MNEs are responsible for most FDI activity, then there is an expected positive correlation between SUMGDP and FDI activity and an expected negative correlation between GDPDIFSQ and FDI activity. The intuition is that with some positive level of trade frictions, larger and more similar sized markets better support the higher fixed costs associated with setting up production across countries (versus exporting) and lead to greater MNE activity.

The third, fourth and fifth terms on the right-hand side of equation (12) are more complicated interaction terms. D2SKDGDPD is an interaction term between three variables; D2, SKD, and GDPD. D2 is a dummy variable that takes the value of " 1 " if the parent country for MNE activity is relatively skilled-labor abundant to the host country, SKD is the difference in relative skilled-labor abundance between the two countries, and GDPD is the real GDP difference between the two countries. ${ }^{11}$ Markusen and Maskus (1999b) argue that this coefficient will have a negative sign if the knowledge capital model is an accurate picture of MNE activity, and will be insignificant if the other alternative MNE models (horizontal and vertical) are more realistic. D2SKDSUMG is another interaction term that

${ }^{11}$ In our regressions, this variable will almost always take the value of " 1 " when we examine U.S. outbound data, because the U.S. is skilled-labor abundant relative to the host country. Likewise, it will often take the value of " 0 " when our dependent variable is inbound FDI activity because the U.S. is the host country in such a circumstance. 
is perhaps the most important variable distinguishing between the alternative MNE models. This variable interacts D2 and SKD (as defined above) with SUMGDP. This variable is hypothesized to have a positive sign if the vertical or knowledge capital MNE models fit the data, but a negative sign if the horizontal MNE model is a better fit. The main intuition behind these differences is that greater skill differences generate greater MNE activity in the vertical model. In contrast, greater skill differences negatively impact horizontal MNE formation. This is because as skill asymmetries rise, so too does the relative cost of skilled labor in the skilled labor scarce country. This leads firms to geographically separate the skilled-intensive headquarters activity from their production activity, i.e. moving firms from horizontal to vertical MNE structures. The knowledge capital model, which like the vertical model permits separation of headquarters and manufacturing, also results in a positive effect on MNE activity from skill asymmetries. Finally, D1SKDSUMG identifies the symmetrically opposite effects of D2SKDSUMG for the situation when the parent country is relatively skilled-labor scarce. It does this by interacting a dummy variable that takes the value of "-1" when the parent is relatively skilled labor scarce and interacts it with SKD and SUMGDP.

In addition to the variables just described, the M-M framework also includes additional control variables. First, distance (DISTANCE) is included to proxy for transport and other trade costs that will affect a firm's decision about whether to become an MNE. Second, trade openness for both the parent and host countries $\left(T_{-} \mathrm{OPEN}_{\mathrm{j}}\right.$ and $\mathrm{T}_{-} \mathrm{OPEN}_{\mathrm{k}}$ ) affect the MNE's ability to trade intermediates and final goods, which then affects the location of MNEs. Greater openness in the host country should lower FDI activity because it lowers trade frictions and makes exporting more attractive. Greater openness in the parent country should increase FDI, since it makes it easier to ship goods back to the parent country from foreign affiliates. FDI openness of the host country $\left(\mathrm{F}_{-} \mathrm{OPEN}_{\mathrm{k}}\right)$ proxies for the costs of setting up an MNE, with greater openness expected to increase FDI activity. In addition to the M-M specified variables, since we are developing instruments, we include the non-treaty tax rates in their estimation. 
Table A3 summarizes the expected signs of our instrumental variables on FDI.

The GDP and trade openness information comes from the Penn-World Tables. ${ }^{12}$ Trade openness is measured as exports plus imports relative to GDP. The FDI openness measure is similar to the trade measure: total inbound affiliate (net of the treaty partner in question) divided by GDP. For details on its construction, see Blonigen and Davies (2000). Distance data comes from the Bali Online Corporation (1999) and is measured as the distance between capital cities. ${ }^{13}$ For skill information, we rely on a relatively new database constructed by World Bank researchers on total mean years of education across countries from 1950-1990 and extrapolate this to $1992 .{ }^{14}$ We use the difference in total mean years of education between the parent and host country as our measure of SKD (skilled-labor abundance difference), and D2 takes the value of "1" when the parent country has a higher total mean years of education. Summary statistics for these data are found in Table A1.

As Table A4 shows, the M-M model does reasonably well in capturing the variation in affiliate sales. Although some coefficients such as that for SUMGDP do not match any of the models of MNE activity, on the whole the data supports either the horizontal or knowledge-capital model of FDI. This is not out of line with Carr, Markusen, and Maskus (forthcoming), Markusen and Maskus (1999a, 1999b), and Blonigen and Davies (2000) which also suggest that horizontal MNEs are more prevalent than vertical MNEs. Curiously, the host non-treaty tax rate is insignificant while the home non-treaty tax, which is not applied to outbound FDI, is negative and significant. If the non-treaty rate is positively correlated with other taxes, this might suggest that capital is fleeing home taxation. It is unclear, however, why a similar result is not found for host taxes.

Table A1: Summary Statistics

\footnotetext{
${ }^{12}$ We use version 5.6 of the Penn-World Tables, which are available online at http://datacentre.chass.utoronto.ca:5680/pwt/. For details on the Penn-World Tables, see Summers and Heston (1991).

${ }^{13}$ This distance calculator can be found at http://www.indo.com.

${ }^{14}$ Our education variable is the mean years of education for both males and females. This data is published by the World Bank and is discussed by Nehru and Dhareshwar (1993).
} 


\begin{tabular}{|c|c|c|c|c|c|}
\hline Variable & Mean & Standard Deviation & Minimum & Maximum & Observations \\
\hline \multicolumn{6}{|l|}{ Treaty countries } \\
\hline Treaty tax & 9.289516 & 6.184768 & 0 & 25 & 124 \\
\hline Foreign non-treaty tax & 23.13056 & 8.754352 & 0 & 45 & 124 \\
\hline Home non-treaty tax & 29.23387 & 8.754352 & 0 & 45 & 124 \\
\hline Foreign Affiliate Sales & 41414.52 & 70781.39 & 0 & 258845 & 124 \\
\hline Home Affiliate Sales & 71320.26 & 107362.8 & 306 & 446422 & 124 \\
\hline Foreign GDP & 1575492 & 2502869 & 65488 & 7765237 & 124 \\
\hline Home GDP & 6917883 & 2296619 & 119834 & 7765237 & 124 \\
\hline \multicolumn{6}{|l|}{ All countries } \\
\hline Foreign non-treaty tax & 21.63923 & 10.47123 & 0 & 45 & 196 \\
\hline Home non-treaty tax & 27.94694 & 7.508357 & 0 & 45 & 196 \\
\hline Foreign Affiliate Sales & 27248.02 & 59276.56 & 0 & 258845 & 196 \\
\hline Home Affiliate Sales & 51931.02 & 90120.23 & 282 & 446422 & 196 \\
\hline Foreign GDP & 1691321 & 2763194 & 17085 & 7765237 & 196 \\
\hline Home GDP & 6603163 & 2692831 & 30373 & 7765237 & 196 \\
\hline \multicolumn{6}{|l|}{1992 data } \\
\hline Treaty tax & 7.5625 & 6.263909 & 0 & 15 & 80 \\
\hline Foreign non-treaty tax & 24.12663 & 9.050412 & 0 & 45 & 80 \\
\hline Home non-treaty tax & 28.025 & 6.174621 & 0 & 35 & 80 \\
\hline Foreign Affiliate Sales & 45608.75 & 59858.1 & 651 & 200826 & 80 \\
\hline Home Affiliate Sales & 73733.2 & 88709.48 & 2370 & 336016 & 80 \\
\hline Foreign F_OPEN & .1406789 & .101259 & .0316996 & .4055 & 80 \\
\hline Home F_OPEN & .074834 & .0309613 & .0060469 & .1645156 & 80 \\
\hline Foreign average education & 9.21845 & 2.157371 & 4.422 & 12.578 & 80 \\
\hline Home average education & 11.00995 & 1.266201 & 6.957 & 11.615 & 80 \\
\hline Foreign T_OPEN & 54.9875 & 32.45174 & 21.9 & 137.14 & 80 \\
\hline Home T_OPEN & 35.144 & 36.31788 & 17.97 & 181.26 & 80 \\
\hline Foreign GDP & 1496344 & 1830909 & 34182.44 & 4575975 & 80 \\
\hline Home GDP & 3540543 & 1840789 & 6584.816 & 4575975 & 80 \\
\hline
\end{tabular}




\begin{tabular}{|l|l|l|l|l|l|}
\hline Distance & 4704.95 & 2171.668 & 455 & 10163 & 80 \\
\hline
\end{tabular}

Table A2: Countries in Sample

1997 data

\begin{tabular}{|c|c|c|c|c|}
\hline Argentina & Australia* & Austria* & Belgium* & Brazil \\
\hline Canada* & Chile & China* & Colombia & Denmark $^{*}$ \\
\hline El Salvador & Finland $^{* \#}$ & France* & Germany* & Guatemala \\
\hline Hong Kong & India* & Indonesia* $^{*}$ & Ireland* & Israel $^{*}$ \\
\hline Italy $^{*}$ & Japan $^{* \#}$ & Kenya & Korea, Republic of* & Kuwait \\
\hline Malaysia & Mexico* & Morocco* & Netherlands* & New Zealand* \\
\hline Norway* & Paraguay & Peru & Philippines* & Poland* \\
\hline Portugal $^{*}$ & Romania* & Russia* & Saudi Arabia\# & Singapore \\
\hline South Africa\# & Spain* & Sweden ${ }^{* \#}$ & Switzerland $^{* \#}$ & Thailand \\
\hline Turkey* & United Kingdom* & Uruguay & Venezuela $^{\#}$ & \\
\hline
\end{tabular}

1992 data

\begin{tabular}{|c|c|c|c|c|}
\hline Australia* & Austria* & Belgium* & Canada* & China* \\
\hline Denmark $^{*}$ & Finland $^{* \#}$ & France* & Germany $^{*}$ & Indonesia $^{*}$ \\
\hline Ireland* & Italy $^{*}$ & $\operatorname{Japan}^{* \#}$ & Luxembourg ${ }^{* \#}$ & Netherlands* \\
\hline Norway* & Spain* & Sweden ${ }^{* \#}$ & Switzerland ${ }^{* \#}$ & United Kingdom* \\
\hline
\end{tabular}

* Indicates treaty in 1997.

" Denotes home country. 
Table A3: Expected Signs of Independent Variables in M-M Empirical Framework

\begin{tabular}{lcl}
\hline Independent Variables & Expected Signs \\
\hline SUMGDP & + & if Horizontal or Knowledge-Capital MNE models \\
GDPDIFSQ & 0 & if Vertical MNE model \\
& - & if Horizontal or Knowledge-Capital MNE models \\
D2SKDGDPD & 0 & if Vertical MNE model \\
& - & if Knowledge-Capital MNE model \\
D2SKDSUMG & 0 & if Horizontal or Vertical MNE models \\
& + & if Vertical or Knowledge-Capital MNE models \\
& - & if Horizontal MNE model \\
D1SKDSUMG & 0 & if Vertical or Knowledge-Capital MNE models \\
& - & if Horizontal MNE model \\
DISTANCE & $?$ & \\
T_OPEN $_{\mathrm{j}}$ & - & if Vertical or Knowledge-Capital MNE models \\
& 0 & if Horizontal MNE model \\
T_OPEN $_{\mathrm{k}}$ & + & \\
F_OPEN $_{\mathrm{k}}$ & + & \\
\hline
\end{tabular}

Subscript $\mathrm{j}$ is the parent while subscript $\mathrm{k}$ is the host. 
Table A4: M-M Instruments for U.S. Inbound and Outbound Affiliate Sales

\begin{tabular}{|c|c|c|}
\hline & Home's affiliate sales & Foreign's affiliate sales \\
\hline Constant & $\begin{array}{c}5145271^{* * *} \\
6.351\end{array}$ & $\begin{array}{c}5860402^{* * * *} \\
7.886\end{array}$ \\
\hline SUMGDP & $\begin{array}{c}-.6149549^{* * *} \\
5.599\end{array}$ & $\begin{array}{c}-.7544814^{* * *} \\
7.518\end{array}$ \\
\hline GDPDIFSQ & $\begin{array}{c}-1.12 \mathrm{e}-07^{* * * *} \\
7.390\end{array}$ & $\begin{array}{c}-1.17 \mathrm{e}-07^{* * * *} \\
8.482\end{array}$ \\
\hline D2SKDGDPD & $\begin{array}{c}.0167123^{* * * *} \\
12.190\end{array}$ & $\begin{array}{c}.0078676^{* * *} \\
6.369\end{array}$ \\
\hline D2SKDSUMG & $\begin{array}{c}-.0179351^{\text {*** }} \\
21.042\end{array}$ & $\begin{array}{c}-.0094152^{* * *} \\
7.223\end{array}$ \\
\hline D1SKDSUMG & $\begin{array}{c}.0019461^{* * *} \\
3.273\end{array}$ & $\begin{array}{c}-.0064275^{* * *} \\
13.668\end{array}$ \\
\hline DISTANCE & $\begin{array}{c}-4.847189^{*} \\
1.975\end{array}$ & $\begin{array}{c}8.528666^{* * * *} \\
5.753\end{array}$ \\
\hline $\mathrm{T}_{-} \mathrm{OPEN}_{\mathrm{j}}$ & $\begin{array}{c}-10.83928 \\
0.174\end{array}$ & $\begin{array}{c}563.4653^{* * * *} \\
3.567\end{array}$ \\
\hline $\mathrm{T}_{\text {OPEN }} \mathrm{k}$ & $\begin{array}{c}107.1193 \\
0.793\end{array}$ & $\begin{array}{c}-371.9834^{* * *} \\
4.248\end{array}$ \\
\hline $\mathrm{F}_{-} \mathrm{OPEN}_{\mathrm{k}}$ & $\begin{array}{c}235393.2^{* * * *} \\
4.827\end{array}$ & $\begin{array}{c}669960.6^{* * * *} \\
4.246\end{array}$ \\
\hline$\overline{\tau_{j}}$ & $\begin{array}{c}-689.9994^{* * * *} \\
2.922\end{array}$ & $\begin{array}{c}-864.666^{* * *} \\
2.196\end{array}$ \\
\hline$\overline{\tau_{k}}$ & $\begin{array}{c}230.1283 \\
0.684\end{array}$ & $\begin{array}{c}153.7815 \\
0.510\end{array}$ \\
\hline $\mathrm{N}$ & & 80 \\
\hline Adjusted $\mathrm{R}^{2}$ & .9487 & .8456 \\
\hline
\end{tabular}

White-corrected t- values in parenthesis.

*** Significant at the $1 \%$ level.

** Significant at the $5 \%$ level.

* Significant at the $10 \%$ level. 